\title{
Gaining the insight of workaholism, its nature and its outcome: A literature review
}

Tabassum, Ayesha $\$

Faculty of Business Administration, Eastern University, Bangladesh (tabassum105@yahoo.com)

Rahman, Tasnuva

Faculty of Business Administration, Eastern University, Bangladesh (tasnuva_miti@yahoo.com)

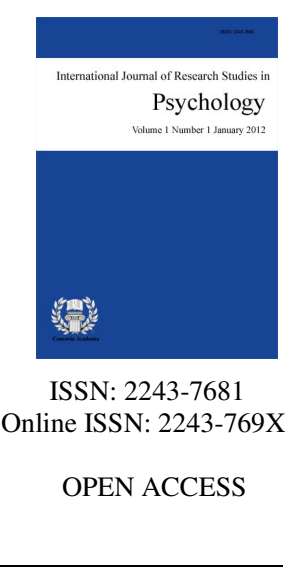

Received: 29 June 2012

Revised: 30 July 2012 DOI: $10.5861 /$ ijrsp.2012.167

Accepted: 4 August 2012

\section{Abstract}

The current study is about exploring the insight of the term 'workaholism'. Since its inception workaholism has grabbed the attention of the academicians. But recently the organizations are also getting concerned about the workaholic people as the managers are facing complexity in terms of managing such work addicted employees. These workaholic employees face greater amount of difficulties both in their work and family life due to their excessive obsession towards work. As a result they face several physical and psychological problems, and at the same time the organizations suffer in terms of productivity. Though this phenomenon is critically important for the development and growth of the employees and also the employers, very few initiatives were taken to explain the term workaholism along with its nature and impact. Several scholars have defined workaholism from different context, which sometimes create perplexity among the scholars and professionals. Thus the present study takes an initiative to explore the definition of workaholism, its nature, its antecedents, and its outcomes through literature review.

Keywords: workaholism; antecedents; positive impact; negative impact; nature of workaholism 


\section{Gaining the insight of workaholism, its nature and its outcome: A literature review}

\section{Introduction}

In recent years, the growing number of dual-earner couples with busy and hectic lifestyle, the challenging business world, and the recent developments in technology has gradually blurred the boundaries between work and home (Jones, Burke, \& Westman, 2006; Ng, Sorensen, \& Feldman, 2007). Accordingly, employees may experience increasing difficulty and pressure in disengaging from work and therefore turn into workaholics (Porter, 2004; Sparks, Faragher, \& Cooper, 2001). Obviously, people may work long hours for many reasons such as economic problems, poor marriage, organizational culture, pressure by their superior, or a strong desire for career development without being addicted to it rather than being motivated by such external or contextual factors, (Schaufeli, Shimazu, \& Taris, 2009). Since the term workaholism was coined by the American minister and psychologist Wayne E. Oates (1968) to denote his own work addiction, it has rapidly become an idiomatic notion.

The most obvious characteristic of workaholics is that they work far beyond what is required. Consequently, they dedicate an excessive amount of time, energy and effort to their work, thereby neglecting other spheres of their life (Buelens \& Poelmans, 2004; Mudrack \& Naughton, 2001). But there is some confusion in the literature as to whether workaholism is entirely "bad" or that it can also be "good" (Schaufeli, Bakker, van der Heijden, \& Prins, 2009). From the onset, workaholism has become a regular and significant topic of discussion in the popular press (Burke, Matthiesen, \& Pallesen, 2006; Taris, Schaufeli, \& Verhoeven, 2005a). But scholarly research has only recently started clarifying the concept and detailing its consequences (e.g. Ng, Sorensen, \& Feldman, 2007). Nevertheless, our knowledge about workaholism is still quite limited because most studies have dealt with the measurement of workaholism and with its correlates, rather than with the nature and impact of it. That's why this article aims to gain a better understanding and knowledge regarding the phenomenon of workaholism.

\section{What is Workaholism?}

The term "workaholism" was coined by Oates (1971), who explained it, as "the compulsion or the uncontrollable need to work incessantly" (p. 11). For a layman workaholism seems synonymous with the fact of excessively hard working (Schaufeli, Shimazu, \& Taris, 2009). These researchers warned that workaholism can be a misleading and vague concept due to the consideration of number of working hours. Researches explored several reasons for working long hours, such as, financial problems, poor marriage, organizational culture, pressure by their supervisor, or a strong desire for career advancement (Schaufeli, Taris, \& Rhenen, 2008). But it does not mean that the person is doing so due to the addiction for work. McMillan and O'Driscoll (2006) mentioned about obsessive inner drive as a core characteristics of workaholic person. Thus workaholism's definition can be established based on two dimensions; one is behavioral (working excessively) and another one cognitive (working compulsively) Schaufeli, Taris \& Rhenen, 2008). While, Snir and Harpaz, (2004, p. 522) defined workaholism as the same behavioral and cognitive terms: as "an individual's sound and considerable allocation of time to work related activities and thoughts, which does not derive from external necessities".

However, the definition of workaholism varies in terms of conceptualization among several researchers. Mosier (1983) defined workaholics simply as those who work at least 50 hours a week. Snir and Zohar (2000) defined workaholism as frequent and considerable allocation of time to work related activities and thoughts. Typically, workaholics work harder than their job prescriptions require and they put much more effort into their jobs than is expected by the organization (Erkmen, Cerik, Bozkurt, \& Ozarslan, 2010). Seybold \& Salomone (1994) described workaholism as over commitment to work. Similarly, Cherrington (1980) sees workaholism as an irrational commitment to excessive work. 
According to Robinson (1997), workaholism is an individual difference characteristic referring to self-imposed demands, compulsive overworking, an incapability to regulate work habits, and overindulgence in work to the exclusion of most other life activities. Machlowitz (1980) prefers to view workaholism as an approach or an attitude toward working, rather than as the amount of time spent at work, since workaholics continue to think about work even when they are not working. Cantarow (1979, p. 56) speculated that workaholic persons have the 'joy of creativity' is an aspect of their personalities. Among these, Schaufeli and colleagues' definition agrees with the most recent study of scholarly definitions that concludes that hard work at the expense of other vital life roles and a strong internal drive to work are two key characteristics of workaholism (Ng, Sorensen, \& Feldman, 2007).

\subsection{Workaholism in terms of excessive work}

Working excessively pertains to actual behavior that is workaholics give a huge amount of time on work-related activities when they get the opportunity to do so (Snir \& Harpaz, 2006; Snir \& Zohar, 2008). As mentioned previously this can be up to 50 hours a week or more (Brett \& Stroh, 2003; Burke, 2001a). In fact they work beyond what is reasonably required to meet the expectations of the organization (Scott, Moore, \& Miceli, 1997). To explain such phenomenon of working excessively, Spence and Robbins (1992) included the fact of work involvement. Some other researchers, such as, McMillan and colleagues (2001) noted that workaholics have the tendency to work anytime at any place.

\subsection{Workaholism in terms of compulsive work}

People may work long hours for economic development and other demands; they may not necessarily work excessively due to the addiction for work (Schaufeli, Taris, \& Van Rhenen, 2007). That's why in addition to long working hours, inner compulsion to work is added as a component of workaholism. This can be better explained by the term "drive to work" (Spence \& Robbins, 1992). Even it can be considered as the personal reluctance to disengage from work as defined by McMillan et al. (2001). Workaholics are obsessed with work activities. They persistently and often think about work, even when not working (Scott, Moore, \& Miceli, 1997). Thus the tendency to work compulsively is represented as cognitive domain of workaholism (Schaufeli, Taris, \& Van Rhenen, 2007).

\subsection{Workaholism defined as an addiction}

According to Porter (1996, p. 71), workaholism should be interpreted as an addiction, that has harmful consequences. Fassel $(1990$, p. 3) also speculated workaholism as a unique addiction, as "it has both a substance component (addiction to adrenaline) and a process component (addiction to the actual process of working)". $\mathrm{Ng}$, Sorensen and Feldman (2007) suggested three theoretical perspectives on addiction, i.e., individual dispositions, socio-cultural experiences, and behavioral reinforcements in the environment. These perspectives propose that people become work addicted as they possess certain personality traits (Scott, Moore, \& Miceli, 1997). Besides these workaholic persons' social or cultural experiences may also facilitate workaholism (Schaufeli, Bakker, van der Heijden, \& Prins, 2009). Finally, Ng, Sorensen, and Feldman (2007) posited that the workaholic behaviors of such persons are reinforced repeatedly that lead them to become addicted towards work.

\section{Characteristics of workaholic people}

Scott, Moore, and Miceli (1997) stated three common characteristics of workaholic person that represent various definitions of workaholism. First, workaholics spend a great deal of time on work activities when given the discretion to do so, thus they are considered as excessively hard workers. Second, workaholics are obsessive workers. Scott and colleagues (1997) characterized them as 'compulsive worker'. These people are unenthusiastic about disengaging from work. Moreover they tirelessly and recurrently think about work when they are not at work. The third trait is that workaholics work beyond what is rationally expected from them to 
meet organizational or economic necessities.

According to Spence and Robbins (1992), there are three properties of workaholism. These are work involvement, drive (a feeling of being compelled to work), and work enjoyment. These three properties are popularly known as 'workaholism triad' in workaholism literature. They explained these three properties with example, such as, spending free time on projects and other constructive activities can be an example of work involvement. Drive towards work can be better understood if one feels obligated to work even when it is not enjoyable. When an individual does more work than is expected, strictly for the fun of it, then it a treated as enjoyment of work (Spence \& Robbins, 1992).

Based on these properties of workaholism, Spence and Robbins (1992) differentiated among three types of people; workaholics, work enthusiasts, and enthusiastic workaholics, whose personality are different in terms of the properties of workaholism. According to Spence and colleague (1992), workaholics tend to score high on work involvement and work compulsion, and low on work enjoyment. But, work enthusiasts score high on work involvement and work enjoyment, and low on the compulsion to work. Finally, enthusiastic workaholics usually score high on all three components (i.e. work involvement, compulsion to work, and work enjoyment).

The validity of the research of Spence and Robbins (1992) was later challenged by Andreassen, Ursin, and Eriksen (2007) and other researchers. Andreassen, Hetland, and Pallesen (2010) distinguished between enthusiastic and non-enthusiastic workaholics. According to these researchers, enthusiastic workaholics are highly involved with work, driven by an internal pressure to work and they find great pleasure in working. But non-enthusiastic workaholics do not derive enjoyment from work involvement and drive to work, though they are highly involved in work-related activities (Andreassen, Hetland, \& Pallesen, 2010).

\section{Typology of workaholism}

Scott, Moore and Miceli (1997) identified three types of workaholism patterns: 1) compulsive-dependent; 2) perfectionist; and 3) achievement-oriented. According to Scott and colleagues, a compulsive-dependent workaholic is an individual who works more than they plan to do. They realize that they are overworking but, they cannot physically and mentally refrain from working terribly. Thus, these types of workaholics are aware of the fact that they are addict, but are unable to overcome the addiction though they know the harmful consequences of addiction. It is likely that compulsive-dependent workaholism is positively related to anxiety, stress, physical and psychological problems; and negatively related to job performance, and job and life satisfaction (Scott, Moore, \& Miceli, 1997).

Perfectionist workaholics are quite similar to compulsive-dependent workaholics as they also show signs of obsessive compulsive personality disorder. However, these persons are very perfectionist workaholics experience an overbearing need for control and are very scrupulous and detail-oriented about work, thus it become very difficult for them to adjust with their team members. As a result these types of workaholics lead to conflict with their coworkers and inefficient use of time at work. Thus perfectionist workaholism is positively related to levels of stress, physical and psychological problems, and hostile interpersonal relationships, as well as to voluntary turnover and absenteeism (Scott, Moore, \& Miceli, 1997).

Finally Scott et al. (1997) described achievement-oriented workaholics are as competitive personalities. These types of workaholics have intense desire for success and a strong career identity. To achieve the goals they have established for themselves, they tend to work excessively with a strong drive. Thus these individuals may not only become physically and psychologically exhausted, but may also extinguish their relationships with their coworkers, friends, and family due to their ravenous competitive nature (Scott, Moore, \& Miceli, 1997). So achievement-oriented workaholism is likely to be positively related to job and life satisfaction, if there are organizational rewards for achievement and personal demands are low. Similarly, achievement-oriented workaholism is also likely to be positively related to physical and psychological health, job performance, and pro-social behavior. Possibly, it is negatively related to stress and voluntary turnover, if there are organizational 
rewards for achievement (Scott, Moore, \& Miceli, 1997).

Robinson (2000) suggested a new type of classification for different types of workaholics, which included relentless workaholics, bulimic workaholics, attention deficit workaholics, and savoring workaholics. Relentless workaholics are high in work initiation and high in work completion, thus treated as stereotypical workaholics by Robinson (2000). These workaholics are probably most comparable to the achievement-oriented workaholics mentioned previously. They may invest long hours on the job and try to exceed what is asked of them due to an inherent drive to work. Thus it can be said that they work compulsively and constantly. According to Robinson (2000) bulimic workaholics are known to be low in work initiation, but high in work completion. These workaholics are not likely to seek out work. But if they are presented with a project, then they tend to obstinately work on it until it is completed. Thus this determination to complete work tasks often leaves the bulimic workaholics mentally and physically exhausted.

Robinson (2000) pointed this as a probable cause of their low likelihood to initiate work. That's why it is said that bulimic workaholics work more occasionally compared to relentless workers. In contrast, attention deficit workaholics are high in work initiation, but low in work completion as they easily lose interest in work tasks. These individuals like to accumulate many different projects at once; as a result they suffer from burnout before the completion of the projects (Robinson, 2000). Finally, Robinson (2000) defined savoring workaholics as low in both work initiation and work completion. They often miss deadlines as they are typically perfectionists and very detail oriented.

Similar to perfectionist workaholics, these persons are prone to obsessive compulsive disorder. That's why they find it difficult to work in teams if the tasks are required to be completed according to their specific guidelines and standards (Robinson, 2000). Recently, Schaufeli, Shimazu, and Taris (2009) classified people in terms of the two dimensions of workaholism defined by them; working excessively and working compulsively. The workaholics classified by Schaufeli and colleagues (2009) are: 1) relaxed workers (score low on both working excessively and working compulsively); 2) hard workers (score high only on working excessively); 3) compulsive workers (score high only on working compulsively); and 4) workaholics (score high on both workaholism scales).

\section{Antecedents of workaholism}

A number of antecedents of workaholism are identified by scholars in previous researches. These include personal demographic characteristics (Burke, 1999a; Spence \& Robbins, 1992), work place characteristics (Burke, 1999a; Spence \& Robbins, 1992), feelings of scantiness and one's needs (Burke, 1999b; Robinson, 1998), and workplace values (Burke, 2001b). Later, Harpaz and Snir (2009) speculated work centrality and expressive orientation to be positively related with workaholism in their research. But they denied the possibility of having any relationship between economic orientation and workaholism, and interpersonal relations and workaholism. Work centrality, where work plays a central and fundamental role in the life of individuals can have an impact on workaholism (Harpaz \& Snir, 2009), because workaholics spend a great deal of time in work activities, which consequently results in their giving up important social, family, or recreational activities (Scott, Moore, \& Miceli, 1997).

Expressive orientation of work considers work aspects such as an interesting job, variety, autonomy, challenging work, and so on (Harpaz \& Snir, 2009). These aspects can create job involvement among employees (Vroom, 1962), which can in turn have an influence on workaholism (Harpaz \& Snir, 2009). On the other hand economic need of individuals is not the motivation for workaholism, as Scott and colleagues (1997) stated that workaholics work beyond what is reasonably considered as necessary to meet basic economic needs. Besides as Harpaz and Snir (2009, p. 299) mentioned "workaholics tend to be critical and contemptuous of co-workers, and display little interest in and great intolerance for the personal lives of assistants and associates", which indicates that workaholics do not work for fulfilling interpersonal needs. 


\section{Negative outcomes of workaholism}

Quite similar as alcoholics, Oates (1971) emphasized that workaholics may suffer from disturbance in terms of health, happiness, interpersonal relationships and social functioning due to excessive and uncontrollable need to work. Similarly Porter (1996) posited that workaholism should be interpreted as an addiction, that is, as extreme and importunate behavior with harmful consequences. From past researches a number of negative consequences are identified. Several researches stated that workaholics report relatively low levels of subjective well-being or happiness (Aziz \& Zickar, 2006; Burke, 2001c, 2008; Schaufeli, Taris, \& Bakker, 2006). Beside workaholics report higher levels of job strains and health complaints (Burke, 1999b, 2000; Burke, Richardsen, \& Mortinussen, 2004; McMillan, O’Driscoll, \& Burke, 2003; Spence \& Robbins, 1992; Taris, Schaufeli, \& Verhoeven, 2005a). Spence and Robins (1992) particularly mentioned about a variety of health problems, ranging from exhaustion to high blood pressure, created due to workaholism.

Workaholics also experience more work-family conflict than others (Bakker, Demerouti, \& Burke, 2009; Burke, 2008; Taris, Schaufeli, \& Verhoeven, 2005b), and levels of marital dissatisfaction are higher among workaholics than among non-workaholics (Robinson, Flowers, \& Carroll, 2001; Burke \& Koksal, 2002). Beside children are affected by parental work addiction in terms of psychological problems into their young adulthood (Robinson, 1998). As a result workaholics experience higher divorce rates, fewer positive feelings about their marriage, and feel less in control of their lives and marriages (Robinson, Flowers, \& Carroll, 2001). Moreover, workaholics report poorer social functioning beside the marital and family dysfunction (McMillan \& O'Driscoll, 2004).

It is also evident from previous literature that workaholics may suffer from reduced job satisfaction and organizational commitment (Burke, 1999b; Burke \& Koskal, 2002; Burke, Richardsen, \& Mortinussen, 2004), as they might be working harder than others but do not receive more rewards for their efforts (Burke, 2001b). In fact workaholics may create more work for themselves by making simple assignments more complicated than necessary, which in turn lessens the enjoyment of work and creates more problems in job (Machlowitz, 1980). The workaholics even face burnout in their jobs due to the excessive work hours and job demand (Schaufeli, Taris, \& Van Rhenen, 2008). As a result, some organizations view workaholism negatively, as workaholics are obsessive, unable to relax, and self-centered, which may create the platform for poor job performance and poor inter-personal relationship with coworkers (Erkmen, Cerik, Bozkurt, \& Ozarslan, 2010).

\subsection{Workaholism and relationship quality}

Researchers suggest that there is a negative relationship between workaholism and relationship quality. It happens because workaholics are willing to sacrifice personal relationships to derive satisfaction from work (Porter, 2001). According to Robinson, Flowers, and Carroll (2001), workaholics have less emotional attachment, and they are less caring than non-workaholics. Thus it contributes towards reduced positive feelings for the spouse, and reduced physical attraction for the spouse. Due to these characteristics of workaholics, Barling, Bluen, and Moss (1990) identified in their study that workaholism is associated with marital dissatisfaction. Consistent with this finding, Burke (1999b) also reported that workaholics are less satisfied in terms of their family life.

\subsection{Workaholism and work-family conflict}

Workaholics differ from non-workaholics regarding the extent to which they experience conflict between work and family (Taris, Schaufeli, \& Verhoeven, 2005b). According to (Greenhaus \& Beutell, 1985, p. 77), "work-to-family conflict is a form of inter-role conflict in which the role pressures from the work and family domains are mutually incompatible in some respect." Thus, participating in the family role becomes more difficult for those persons who are more involved in the work role, i.e. the workaholics. This happens because workaholics devote more time and efforts to work; thus leaving them with small amount of time and efforts to 
devote to their family (Hobfoll, 2002). Accordingly some studies have explored a positive relationship between workaholism and work- family conflict (e.g., Bonebright, Clay, \& Ankenmann, 2000; Taris et al., 2005).

\subsection{Workaholism and well-being}

Several researches explored an association between workaholism and poor health of workaholic persons. As workaholic people spend an excessive amount of time on their work and they frequently think about work when they are not at work, they get few opportunities to recover from their excessive efforts (Shimazu \& Schaufeli, 2009). As a result they become emotionally or cognitively exhausted over time (Taris, Schaufeli, \& Verhoeven, 2005b). There are evidences that workaholic people suffer in diminished sleep quality (Kubota, Shimazu, Kawakami, Takahashi, Nakata, \& Schaufeli, 2010), and worse psychological health (e.g., Burke, 2000; Schaufeli, Taris, \& Bakker, 2008; Shimazu \& Schaufeli, 2009).

As researches have showed that workalism leads to reduced job satisfaction (Bonebright, Clay, \& Ankenmann, 2000; Burke, 2001b, 2008; Burke \& Koskal, 2002), increased marital problems (Robinson, Flowers, \& Caroll, 2001), lower family satisfaction (Burke, 1999b), lower relationship satisfaction (Bakker et al., 2009), and greater work-family conflict (Bakker et al., 2009; Bonebright, Clay, \& Ankenmann, 2000; Taris, Schaufeli, \& Verhoeven, 2005b); thus all these can create an additional psychological dilemma on the workaholics. Besides, workaholism is also associated with individual's partner's well-being. It happens because the individual's work-family conflict can lead to increased social undermining and higher home demands for the partner, which in turn results in greater family-work conflict for the partner a well (Shimazu, Demerouti, Bakker, Shimada, \& Kawakami, 2011). Thus the partner's psychological health is also affected.

\subsection{Workaholism and burnout}

Maslach (1986) considered workaholism as a root cause of burnout. Workaholics become eventually exhausted and burned out as they spend too much energy at work, which they cannot counterbalance properly (Schaufeli, Bakker, van der Heijden, \& Prins, 2009). Schaufeli et al. (2009) also posit that intra-role conflicts at work consume the workaholic's energy, which may lead to burnout. It can also be ascertained that the workaholics who face greater work-family conflict may suffer in burnout as they are dissatisfied with their family or personal life. As a whole, several empirical studies report a positive association between workaholism and burnout (e.g. Andreassen, Ursin, \& Eriksen, 2007; Burke, 2008; Burke, Richardsen, \& Mortinussen, 2004; Schaufeli, Taris, \& Bakker, 2008; Taris, Schaufeli, \& Verhoeven, 2005b).

\subsection{Workaholism and job performance}

The relationship between workaholism and job performance is not clear from the previous studies. According to Schaufeli, Taris, and Bakker (2006), job performance can be split into in-role performance and extra-role performance. In-role performance can be seen as the work that one is supposed to do as typical job activities. Whereas, extra-role performance is defined as non-compulsory behaviors that directly promote the effective functioning of an organization, but do not necessarily directly influence a job incumbent's productivity. It is also known as organizational citizenship behavior (Schaufeli, Taris, \& Bakker, 2006). Schaufeli et al. found that workaholics work hard rather than smart. They create difficulties for their co-workers, suffer from perfectionism. At the same time they are rigid and inflexible and do not like to delegate authority. Thus these researchers found a weak positive relationship between workaholism, in terms of working excessively and working compulsively with extra-role performance, but did not find any relationship with in-role performance. Later on, Shimazu and Schaufeli (2009) measured performance as overall performance and found that workaholism was weakly negatively related. They also found that only the working compulsively component was significantly related to performance. A negative relationship between workaholism and job performance was also suggested by Burke (2001b). 


\section{Positive outcomes of workaholism}

In contrast of negative consequences, some writers viewed workaholism in positive terms. Workaholism can be considered as good, because it includes the aspect of work enjoyment, which comes very close to work engagement in a positive manner (Schaufeli, Salanova, Gonzalez-Roma, \& Bakker, 2002). This type of work related state of mind can be characterized by dynamism, devotion, and incorporation (Schaufeli, Salanova, Gonzalez-Roma, \& Bakker, 2002). Engaged employees consider their work as challenging, as they have a sense of energetic and effective connection with their work instead of stressful and demanding (Bakker, Schaufeli, Leiter \& Taris, 2008). This phenomenon can reduce job burnout and increase job satisfaction and organizational commitment (Schaufeli, Taris, \& Van Rhenen, 2008). Peiperl and Jones (2001, p. 388) also see workaholics as "hard workers who enjoy and get a lot out of their work."

Machlowitz (1980) after conducting a qualitative interview and studying on more than 100 workaholics and concluded that they are satisfied with their lives. Cantarow (1979) emphasized that workaholics seek passionate involvement and gratification through work. Thus the workaholics can be considered as "hyper-performers" from an organizational perspective (Korn, Pratt, \& Lambrou, 1987). Some organizations thus view workaholism positively (Erkmen, Cerik, Bozkurt, \& Ozarslan, 2010), as workaholics are dedicated employees who are passionate about and captivated of work, so managers would want to hire, develop and retain them. Workaholic organizational leaders often view workaholism as a positive attribute, and appreciate, praise, expect and demand workaholic behavior from their employees (Shimazu \& Schaufeli, 2009).

\section{Conclusion}

Though the term 'workaholism' is widely used, a little consensus has been found in terms of definition and impact of it. Most of the researchers focused their studies by relating workaholism with the relevant outcomes of workaholism rather than explaining the term workaholism clearly. Thus in future the researchers may take initiatives to define and explain workaholism in a coherent manner. By understanding the nature of workaholism, Human Resources Managers or professionals can analyze and control workaholic behavior of employees which may have an influence on their job performance. Above all, the impact of employees' workaholic behavior is important in terms of its relationship with organizational outcomes such as job satisfaction, organizational commitment, absenteeism tendency, organizational citizenship and productivity. Accordingly, this study intended to draw managers' and academicians' attention to the dynamics and nature of workaholism.

\section{References:}

Andreassen, C. S., Hetland, J., \& Pallesen, S. (2010). The relationship between 'Workaholism', basic beeds satisfaction at work and personality. European Journal of Personality, 24, 3-17. $<$ http://dx.doi.org/10.1002/per.737>

Andreassen, C. S., Ursin, H., \& Eriksen, H. R. (2007). The relationship between strong motivation to work, 'workaholism', and health. Psychology and Health, 22, 615-629.

Aziz, S., \& Zickar, M. J. (2006). A cluster analysis investigation of workaholism as a syndrome. Journal of Occupational Health Psychology, 11, 52-62. <http://dx.doi.org/10.1037/1076-8998.11.1.52>

Bakker, A. B., Demerouti, E., \& Burke, R. (2009). Workaholism and relationship quality: a spillover-crossover perspective. Journal of Occupational Health Psychology, 14, 23-33. $<$ http://dx.doi.org/10.1037/a0013290>

Bakker, A. B., Schaufeli, W. B., Leiter, M. P., \& Taris, T. W. (2008). Work engagement: An emerging concept in occupational health psychology. Work \& Stress, 22, 187-200. $<$ http://dx.doi.org/10.1080/02678370802393649>

Barling, J., Bluen, S., \& Moss, V. (1990). Type A behavior and marital dissatisfaction: Disentangling the effects of achievement striving and impatience-irritability. Journal of Psychology, 124, 311-319.

Bonebright, C. A., Clay, D. L., \& Ankenmann, R. D. (2000). The relationship of workaholism with work-life 
conflict, life satisfaction, and purpose in life. Journal of Counseling Psychology, 47, 469-477. $<$ http://dx.doi.org/10.1037/0022-0167.47.4.469>

Brett, J. M., \& Stroh, L. K. (2003). Working 61 plus hours a week: Why do managers do it? Journal of Applied Psychology, 88, 67-78. <http://dx.doi.org/10.1037/0021-9010.88.1.67>

Buelens, M., \& Poelmans, S. Enriching the Spence and Robbins' typology of workaholism. Demographic, motivational and organizational correlates. Journal of Organizational Change Management, 17(5), 440-458. <http://dx.doi.org/10.1108/09534810410554470>

Burke, R J., Matthiesen, S. B., \& Pallesen, S. (2006). Personality correlates of workaholism. Personality and Individual Differences, 40, 1223-1233. <http://dx.doi.org/10.1016/j.paid.2005.10.017>

Burke, R. J. (19991). It's not how hard you work but how you work hard: Evaluating workaholism components. International Journal of Stress Management, 6, 225-240. <http://dx.doi.org/10.1023/A:1021936220220>

Burke, R. J. (1999b). Workaholism in organizations: The role of personal beliefs and fears. Anxiety, Stress and Coping, 13, 1-12.

Burke, R. J. (2000). Workaholism in organizations: Psychological and physical wellbeing consequences. Stress Medicine, 16, 11-16. $<$ http://dx.doi.org/10.1002/(SICI)1099-1700(200001)16:1<11::AID-SMI825>3.0.CO;2-U>

Burke, R. J. (2001a). Predictors of workaholism components and behaviors. International Journal of Stress Management, 8, 113-127. <http://dx.doi.org/10.1023/A:1009577230051>

Burke, R. J. (2001b). Workaholism components, job satisfaction, and career progress. Journal of Applied Social Psychology, 31, 2339-2356. <http://dx.doi.org/10.1111/j.1559-1816.2001.tb00179.x>

Burke, R. J. (2001c). Workaholism in organizations: The role of organizational values. Personnel Review, 30, 637-645. <http://dx.doi.org/10.1108/EUM0000000005977>

Burke, R. J. (2008). Work motivations, satisfactions, and health: Passion versus addiction. In R. J. Burke \& C. L. Cooper (Eds.), The long working hours culture. Causes, consequences and choices (pp. 227-251). Bingley, UK: Emerald.

Burke, R. J., \& Koksal, H. (2002). Workaholism among a sample of Turkish managers and professionals: An exploratory study. Psychological Reports, 91, 60-68.

Burke, R. J., Richardsen, A. M., \& Mortinussen, M. (2004). Workaholism among Norwegian managers: Work and well-being outcomes. Journal of Organizational Change Management, 7, 459-470. $<$ http://dx.doi.org/10.1108/09534810410554489>

Cantarow, E. (1979). Women workaholics. Mother Jones, 6, 56-58.

Cherrington, D. J. (1980). The work ethic. New York: American Management Association.

Erkmen, T., Cerik, S, Bozkurt, S., Ozaslan, E. (2010). The development of Spence and Robbins Workaholism Scale with its validity and reliability measurement. International Journal of Business and Management Studies, 2(1), 89-95.

Fassel, D. (1990). Working ourselves to death: The high cost of workaholism and the rewards of recovery. New York: Harper Collins.

Greenhaus, J. H., \& Beutell, N. J. (1985). Sources of conflict between work and family roles. Academy of Management Review, 10, 76-88.

Harpaz, I., \& Snir, R. (2003). Workaholism: Its definition and nature. Human Relations, 56(3), 291-319. $<$ http://dx.doi.org/10.1177/0018726703056003613>

Hobfoll, S. E. (2002). Social and psychological resources and adaptation. Review of General Psychology, 6 , 307-324. <http://dx.doi.org/10.1037/1089-2680.6.4.307>

Jones, F., Burke, R. J., \& Westman, M. (2006). Work-life balance: Key issues. In F. Jones, R. J. Burke \& M. Westman (Eds.), Work-life balance: A psychological perspective (pp. 1-38). East Sussex: Psychology Press.

Korn, E. R., Pratt, G. J., \& Lambrou, P. T. (1987). Hyper-performance: The A.I.M. strategy for releasing your business potential. New York: John Wiley.

Kubota, K., Shimazu, A., Kawakami, N., Takahashi, M., Nakata, A., \& Schaufeli, W. B. (2010). Association 
Tabassum, A. \& Rahman, T.

between workaholism and sleep problems among hospital nurses. Industrial Health, 48, 864-871. <http://dx.doi.org/10.2486/indhealth.MS1139>

Machlowitz, M. (1980). Workaholics. Living with them, working with them. Reading, MA: Addison-Wesley.

Maslach, C. (1986). Stress, burnout and workaholism. In R. R. Killberg, P. E. Nathan \& R. W. Thoreson (Eds.), Professionals in distress: Issues, syndromes and solutions in psychology (pp.53-73). Washington, DC: American Psychological Association. <http://dx.doi.org/10.1037/10056-004>

McMillan, L. H. W., \& O’Driscoll, M. P. (2004). Workaholism and health: Implications for organizations. Journal of Organizational Change Management, 17, 509-519. $<$ http://dx.doi.org/10.1108/09534810410554515>

McMillan, L. H. W., \& O’Driscoll, M. P. (2006). Exploring new frontiers to generate an integrated definition of workaholism. In R. Burke (Ed.), Research companion to working time and work addiction (pp. 89-107). Cheltenham, UK: Edward Elgar.

McMillan, L. H. W., O’Driscoll, M. P., \& Burke, R. J. (2003). Workaholism: A review of theory, research, and future directions. In C. L. Cooper \& I. T. Robertson (Eds.), International review of industrial and organizational psychology (Vol. 18, pp. 167-189). New York: Wiley.

McMillan, L. H. W., O’Driscoll, M. P., Marsh, N. V., \& Brady, E. C. (2001). Understanding workaholism: Data synthesis, theoretical critique, and future design strategies. International Journal of Stress Management, 8, 69-91. <http://dx.doi.org/10.1023/A:1009573129142>

Mosier, S. K. (1983). Workaholics: An analysis of their stress, success and priorities. Unpublished masteral thesis, University of Texas at Austin.

Mudrack, P. E., \& Naughton, T. J. (2001). The assessment of workaholism as behavioral tendencies: scale development and preliminary testing. International Journal of Stress Management, 8, 93-112. $<$ http://dx.doi.org/10.1023/A:1009525213213>

Ng, T. W. H., Sorensen, K. L., \& Feldman, D. C. (2007). Dimensions, antecedents, and consequences of workaholism: A conceptual integration and extension. Journal of Organizational Behavior, 28, 111-136. $<$ http://dx.doi.org/10.1002/job.424>

Oates, W. E. (1971). Confessions of a workaholic: The facts about work addiction. New York: World Publishing.

Peiperl, M., \& Jones, B. (2001). Workaholics and overworkers: Productivity or pathology? Group and Organization Management, 26, 369-393. <http://dx.doi.org/10.1177/1059601101263007>

Porter, G. (1996). The organizational impact of workaholism: Suggestions for researching the negative outcomes of excessive work. Journal of Occupational Health Psychology, 1(1), 70-84. $<$ http://dx.doi.org/10.1037/1076-8998.1.1.70>

Porter, G. (2001). Workaholic tendencies and the high potential for stress among co-workers. International Journal of Stress Management, 8, 147-164. <http://dx.doi.org/10.1023/A:1009581330960>

Porter, G. (2004). Work, work ethic, work excess. Journal of Organizational Change Management, 17(5), 424-439. <http://dx.doi.org/10.1108/09534810410554461>

Porter, G. (2006), Profiles of workaholism among high-tech managers. Career Development International, 11(5), 440-462. <http://dx.doi.org/10.1108/13620430610683061>

Robinson, B. E. (1997). Work addiction and the family: Conceptual research considerations. Early Child Development and Care, 137, 77-92. <http://dx.doi.org/10.1080/0300443971370106>

Robinson, B. E. (1998). The workaholic family: A clinical perspective. American Journal of Family Therapy, 26 (Jan.-March), 65-76. <http://dx.doi.org/10.1080/01926189808251087>

Robinson, B. E. (2000). Workaholism: Bridging the gap between workplace, socio-cultural, and family research. Journal of Employment Counseling, 37(1), 31-47. $<$ http://dx.doi.org/10.1002/j.2161-1920.2000.tb01024.x >

Robinson, B. E., Flowers, C., \& Carroll, J. (2001). Work stress and marriage: A theoretical model examining the relationships between workaholism and marital cohesion. International Journal of Stress Management, 8, 165-175. <http://dx.doi.org/10.1023/A:1009533415030>

Schaufeli, W. B., Bakker, A. B., Van der Heijden, F. M. M. A., \& Prins, J. T. (2009). Workaholism among medical residents: It is the combination of working excessively and compulsively that counts. 
International Journal of Stress Management, 16, 249-272. <http://dx.doi.org/10.1037/a0017537>

Schaufeli, W. B., Bakker, A. B., Van der Heijden, F. M. M. A., \& Prins, J. T. (2009). Workaholism, burnout and well-being among junior doctors: The mediating role of role conflict. Work \& Stress, 23, 155-172. $<$ http://dx.doi.org/10.1080/02678370902834021>

Schaufeli, W. B., Salanova, M., Gonzalez-Roma, V., \& Bakker, A. B. (2002). The measurement of engagement and burnout and: A confirmative analytic approach. Journal of Happiness Studies, 3, 71-92. $<$ http://dx.doi.org/10.1023/A:1015630930326>

Schaufeli, W. B., Shimazu, A., \& Taris, T. W. (2009). Being driven to work excessively hard: the evaluation of a two-factor measure of workaholism in the Netherlands and Japan. Cross-Cultural Research, 43, 320-348. <http://dx.doi.org/10.1177/1069397109337239>

Schaufeli, W. B., Taris, T. W., \& Bakker, A. B. (2006). Dr. Jeckyll or Mr. Hyde: On the differences between work engagement and workaholism. In R. J. Burke (Ed.), Research companion to working time and work addiction. Cheltenham Glos, UK: Edward Elgar.

Schaufeli, W. B., Taris, T. W., \& Bakker, A. B. (2008). It takes two to tango: Workaholism is working excessively and working compulsively. In R. J. Burke \& C. L. Cooper (Eds.), The long work hours culture. Causes, consequences and choices (pp. 203-226). Bingley, UK: Emerald.

Schaufeli, W. B., Taris, T. W., \& Van Rhenen, W. (2008). Workaholism, burnout, and engagement: Three of a kind or three different kinds of employee well-being. Journal of Applied Psychology: An International Review, 57, 173-203. <http://dx.doi.org/10.1111/j.1464-0597.2007.00285.x >

Scott, K. S., Moore, K. S., \& Miceli, M. P. (1997). An exploration of the meaning and consequences of workaholism. Human Relations, 50, 287-314. <http://dx.doi.org/10.1177/001872679705000304>

Seybold, K. C., \& Salomone, P. R. (1994).Understanding workaholism: A review of causes and counseling approaches. Journal of Counseling and Development, 73, 4-10. $<$ http://dx.doi.org/10.1002/j.1556-6676.1994.tb01702.x >

Shimazu, A., \& Schaufeli, W. B. (2008). Does distraction facilitate problem-focused coping with job stress? A 1 year longitudinal study. Journal of Behavioral Medicine, 30, 423-434. $<$ http://dx.doi.org/10.1007/s10865-007-9109-4>

Shimazu, A., \& Schaufeli, W. B. (2009). Is workaholism good or bad for employee well-being? The distinctiveness of workaholism and work engagement among Japanese employees. Industrial Health, 47, 495-502. <http://dx.doi.org/10.2486/indhealth.47.495>

Shimazu, A., Demerouti, E., Bakker, A. B., Shimada, K., \& Kawakami, N. (2011). Workaholism and well-being among Japanese dual-earner couples: A spillover-crossover perspective. Social Science and Medicine, 73, 399-409. <http://dx.doi.org/10.1016/j.socscimed.2011.05.049>

Shimazu, A., Schaufeli, W. B., Kosugi, S., Suzuki, A., Nashiwa, H, Kato, A., Sakamoto, M., Irimajiri, H., Amano, S., Hirohata, K., Goto, R., \& Kitaoka-Higashiguchi, K. (2008) Work Engagement in Japan: validation of the Japanese version of the Utrecht Work Engagement Scale. Applied Psychology International Review, 57, 510-23. <http://dx.doi.org/10.1111/j.1464-0597.2008.00333.x $>$

Snir, R., \& Harpaz, I. (2004). Attitudinal and demographic antecedents of workaholism. Journal of Organizational Change Management, 17, 520-536. <http://dx.doi.org/10.1108/09534810410554524>

Snir, R., \& Harpaz, I. (2006). The workaholism phenomenon: A cross-national perspective. Career Development International, 11(5), 374-393. <http://dx.doi.org/10.1108/13620430610683034>

Snir, R., \& Zohar, D. (2008). Workaholism as discretionary time investment at work: An experience-sampling study. Applied Psychology: An International Review, 57, 109-127.

$<$ http://dx.doi.org/10.1111/j.1464-0597.2006.00270.x >

Sparks, K., Faragher, B., \& Cooper, C. L. (2001). Well-being and occupational health in the 21st century workplace. Well-being and occupational health in the 21 st century workplace. Journal of Occupational and Organizational Psychology, 74, 489-509. <http://dx.doi.org/10.1348/096317901167497>

Spence, J. T., \& Robbins, A. S. (1992). Workaholism: Definition, measurement, and preliminary results. Journal of Personality Assessment, 58(1), 160-178. <http://dx.doi.org/10.1207/s15327752jpa5801_15>

Taris, T. W., Schaufeli, W. B., \& Verhoeven, L. C. (2005a). Internal and external validation of the Dutch Work 
Tabassum, A. \& Rahman, T.

Addiction Risk Test: Implications for jobs and non-work conflict. Applied Psychology: An international Review, 54, 37-60. <http://dx.doi.org/10.1111/j.1464-0597.2005.00195.x >

Taris, T. W., Schaufeli, W. B., \& Verhoeven, L. C. (2005b). Workaholism in the Netherlands: Measurement and implications for job strain and work-nonwork conflict. Applied Psychology: An International Review, $54,37-60$.

Vroom, V. H. (1962). Industrial social psychology. In G. Lindzey \& E. Aronson (Eds.), The handbook of social psychology (2nd ed., pp. 196-268). Reading, MA: Addison-Wesley. 